\title{
EFISIENSI ADSORBSI GAS KARBONDIOKSIDA PADA BIOGAS DENGAN MENGGUNAKAN VARIASI UKURAN ADSORBEN (KARBON AKTIF)
}

\author{
Purwinda Iriani, Yanti Suprianti,Angga Kurniawan \\ Jurusan Teknik Konversi Energi Politeknik Negeri Bandung \\ Email : purwinda.iriani@polban.ac.id
}

\begin{abstract}
ABSTRAK
Penggunaan biogas sebagai sumber energy terbarukan mulai meluas, tidak hanya di sector rumah tangga, namun hingga sector industry. Salah satu kendala dalam menghasilkan biogas dengan nilai kalor yang tinggi adalah dengan mereduksi kandungan gas karbon dioksida yang turut terbentuk dan menjadi hasil samping dari produksi biogas. Komposisi biogas terdiri dari 20-45\% karbon dioksida $\left(\mathrm{CO}_{2}\right)$, 50-70\% metana $\left(\mathrm{CH}_{4}\right)$ dan sisanya sebagian kecil gas lain seperti $\mathrm{H}_{2} \mathrm{~S}, \mathrm{CO}, \mathrm{O}_{2}$ dan $\mathrm{N}_{2}$. Upaya pengurangan kadar gas $\mathrm{CO} 2$ dalam suatu biogas dapat dilakukan melalui metode adsorpsi dengan menggunakan arang aktif sebagai adsorben. Persentase gas $\mathrm{CO} 2$ yang teradsorbsi tergantung pada tuas permukaan adsorben yang dilaluinya.

Pada penelitian ini, dilakukan pengujian terhadap kolom adsorber berbahan karbon aktif dengan 3 ukuran berbeda, yaitu karbon aktif ukuran 8 mesh, 16 mesh dan 32 mesh, yang dioperasikan selama 15 menit. Dari hasil pengujian menunjukkan bahwa karbon aktif ukuran 32 mesh memiliki rata-rata persentase efektivitas adsorbsi paling tinggi, yaitu 83,84\%. Pada adsorben berukuran 8 mesh dan 16 mesh, masing-masing memiliki rata-rata persentase adsorbsi $61,51 \%$ dan $47,44 \%$. Dari pengujian yang telah dilakukan terlihat bahwa ukuran karbon aktif mempengaruhi efektivitas adsorpsi dalam pemurnian biogas, dan hasil pemunian terbaik diperoleh dengan menggunakan karbon aktif ukuran 32 mesh dengan efektivitas adsorpsi 90,37\%, kandungan metana setelah pemurnian $88,28 \%$, nilai kalor biogas $28968,86 \mathrm{~kJ} / \mathrm{m}^{3}$ dan potensi energi biogas selama 15 menit $476,524 \mathrm{~kJ}$.
\end{abstract}

Kata Kunci : Adsorpsi, Biogas, Nilai Kalor, Karbon Aktif, Pemurnian Biogas.

\begin{abstract}
The utilization of biogas as one of the renewable energy sources has been expanding, not only in the household sector, but until the industry sector. One of the obstacles in producing biogas with a high calorific value is to reduce the content of carbon dioxide gas which helped form and becomes a byproduct of the production of biogas. The composition of biogas is composed of 20-45\% carbon dioxide (CO2), 50-70\% methane (CH4) and the remaining fraction of other gases such as $\mathrm{H} 2 \mathrm{~S}, \mathrm{CO}, \mathrm{O} 2$ and $\mathrm{N} 2$. The effort to reduce the levels of $\mathrm{CO} 2$ in a gas can be done through adsorption methods using activated charcoal as an adsorbent. The percentage of $\mathrm{CO} 2$ gas adsorbed depends on the surface area of the adsorbent in its path.

In this study, conducted testing of the adsorber column made of activated carbon with three different sizes, namely activated carbon size 8 mesh, 16 mesh and 32 mesh, which operated for 15 minutes. The result showed that 32 meh of activated carbon reach the highest of average percentage, $83.84 \%$. The 8 mesh and 16 mesh, showed the average adsorption percentage of $61.51 \%$ and $47.44 \%$, respectively. The size of the activated carbon particles gave an adsorption affect to the effectiveness of biogas purification. The results obtained that 32 mesh activated carbon gave $90.37 \%$ adsorption effectiveness the methane content $88.28 \%$ after purification, biogas calorific value of $28968,86 \mathrm{~kJ} / \mathrm{m} 3$ and the energy potential of biogas for 15 minutes $476.524 \mathrm{~kJ}$.
\end{abstract}

Keywords : adsorption, Biogas, value of heat, Activated Carbon, Biogas Purification

\section{PENDUHULUAN}

Biogas merupakan gas yang dihasilkan dari proses fermentasi bahan-bahan organik oleh bakteri yang dilakukan secara anaerob (tanpa udara). Produk utama biogas yang digunakan sebagai bahan bakar adalah metana
$\left(\mathrm{CH}_{4}\right)$. Hanya saja dalam proses biogas, gas yang terbentuk tidak hanya $\mathrm{CH}_{4}$, akan tetapi juga dihasilkan kandungan gas lain seperti $\mathrm{CO}_{2}, \mathrm{H}_{2} \mathrm{~S}, \mathrm{~N}_{2}$ dan juga $\mathrm{H}_{2}$. Adapun komposisi gas terbesar hasil dari biogas menurut Meynel (1976) adalah: $\mathrm{CH}_{4}=55-70 \%$ dan $\mathrm{CO}_{2}=25$ $45 \%$ [1]. 
Keberadaan gas $\mathrm{CO}_{2}$ dalam biogas dapat menurunkan nilai kalor biogas dan akan mengganggu proses pembakaran karena $\mathrm{CO}_{2}$ mempunyai sifat yang tidak bisa dibakar [2]. Oleh karena itu, untuk meningkatan kualitas gas yang dihasilkan dari biogas dilakukan proses purifikasi (pemurnian) biogas dari gas $\mathrm{CO}_{2}$ agar kandungan $\mathrm{CH}_{4}$ dalam biogas menjadi lebih tinggi dan dapat digunakan sebagai bahan bakar biometan yang secara standar minimal memiliki kandungan $\mathrm{CH}_{4}$ dalam gas $=90 \%[3]$.

Pemurnian biogas merupakan upaya untuk menghilangkan atau mengurangi zat pengotor dalam biogas seperti $\mathrm{CO}_{2}, \mathrm{H}_{2} \mathrm{~S}$ maupun $\mathrm{H}_{2} \mathrm{O}$ yang dapat mengurangi performa dari biogas itu sendiri guna meningkatkan nilai guna dari biogas dan memperolah manfaat biogas yang lebih optimal [4].

Terdapat berbagai teknologi untuk pemurnian biogas, diantaranya adsorpsi menggunakan pemisahan menggunakan membran, kriogenik, water scruber dan metode adsorpsi. Pemurnian biogas menggunakan metode adsorpsi salah satunya adalah dengan menggunakan karbon aktif sebagai adsorben. Salah satu yang mempengaruhi Efektifitas adsorpsi akan semakin tinggi apabila luas permukaan adsorben semakin besar.

Sementara itu semakin kecil ukuran karbon aktif akan membuat total luas permukaan karbon aktif menjadi semakin besar dan juga memperbesar area kontak karbon aktif dengan biogas yag dilewatkan ke dalam kolom, sehingga hal tersebut akan membuat jumlah $\mathrm{CO}_{2}$ dalam biogas yang teradsosrpsi oleh karbon aktif menjadi semakin banyak

Penelitian ini dilakukan untuk mengetahui pengaruh ukuran karbon aktif terhadap efektivitas adsorpsi $\mathrm{CO}_{2}$ pada pemurnian biogas.

Proses pembentukan biogas dibagi menjadi empat tahapan yakni tahap hidrolisis, tahap acidogenesis, tahap accetogenesis dan tahap methanogenesis [5].

Biogas yang dihasilkan sebagian besar terdiri dari $50-70 \%$ metana $\left(\mathrm{CH}_{4}\right), 30-40 \%$ karbon dioksida $\left(\mathrm{CO}_{2}\right)$ dan gas lainnya dalam jumlah kecil [6]. Biogas memiliki kandungan gas metana $\left(\mathrm{CH}_{4}\right)$ dalam persentase yang cukup tinggi dan memiliki suhu pembakaran antara $650-750{ }^{\circ} \mathrm{C}$ sehingga dapat dijadikan sebagai bahan bakar. Disamping itu terdapat gas-gas lain yang komposisinya dapat dilihat pada Tabel 1.

Tabel 1 Komposisi Biogas [1]

\begin{tabular}{|l|l|c|}
\hline No & \multicolumn{1}{|c|}{$\begin{array}{c}\text { Komponen } \\
\text { Gas }\end{array}$} & $\begin{array}{c}\text { Komposisi } \\
(\%)\end{array}$ \\
\hline 1 & Metana $\left(\mathrm{CH}_{4}\right)$ & $55-70$ \\
\hline 2 & Karbon Dioksida $\left(\mathrm{CO}_{2}\right)$ & $25-45$ \\
\hline 3 & Nitrogen $\left(\mathrm{N}_{2}\right)$ & $0-0,3$ \\
\hline 4 & Oksigen $\left(\mathrm{O}_{2}\right)$ & $1-5$ \\
\hline 5 & $\begin{array}{l}\text { Karbon Monoksida } \\
(\mathrm{CO})\end{array}$ & - \\
\hline 6 & Hidrogen Sulfida $\left(\mathrm{H}_{2} \mathrm{~S}\right)$ & $0-3$ \\
\hline
\end{tabular}

Kemurnian biogas menjadi pertimbangan yang sangat penting karena berpengaruh terhadap nilai kalor/panas yang dihasilkan. Pemurnian biogas merupakan upaya untuk menghilangkan atau mengurangi zat pengotor dalam biogas seperti $\mathrm{CO}_{2}, \mathrm{H}_{2} \mathrm{~S}$ maupun $\mathrm{H}_{2} \mathrm{O}$ yang dapat mengurangi performa dari biogas itu sendiri guna meningkatkan nilai guna dari biogas dan memperolah manfaat biogas yang lebih optimal [4].

Adapun tujuan dari pemurnian biogas adalah untuk menghilangkan atau mengurangi kandungan $\mathrm{CO}_{2}$ dan $\mathrm{H}_{2} \mathrm{~S}$ sehingga dapat meningkatkan nilai kalor biogas. Selain itu juga proses pemurnian biogas juga bertujuan untuk menghindari masalah korosi, lingkungan, dan kesehatan.

Secara umum, adsorpsi adalah proses penggumpalan substansi terlarut (soluble) yang ada dalam larutan oleh permukaan zat atau benda penyerap, dimana terjadi suatu ikatan kimia-fisika antara substansi dengan penyerapnya. Proses adsorpsi dapat saja terjadi antara cairan dan gas, padatan, atau cairan lain. Adsorpsi fisik terjadi karena adanya ikatan van der Waals, dan bila ikatan tarik antar molekul zat terlarut dengan zat penyerapnya lebih besar dari ikatan antara molekul zat terlarut dengan pelarutnya, maka zat terlarut akan dapat diadsorpsi. Sedangkan adsorpsi kimia merupakan hasil dari reaksi kimia antara molekul adsorbat dan adsorben dimana terjadi pertukaran elektron [7].

Pada umumnya faktor-faktor yang mempengaruhi proses adsorpsi adalah sebagai berikut : 
21 Jenis adsorbat, dari jenis adsorbat yang dapat mempengaruhi adsorpsi adalah ukuran molekul adsorbat, kepolaran zat, konsentrasi adsorbat, tekanan adsorbat, temperatur Absolut,

22 Karakteristik adsorben, yakni meliputi kemurnian adsorben, luas permukaan dan volume pori adsorben [8], $\mathrm{pH}$ larutan [9], waktu kontak [7], dan jumlah stage.

Karbon aktif adalah senyawa karbon yang telah diproses dengan cara diaktivasi supaya mempunyai banyak pori-pori, sehingga mempunyai luas permukaan yang sangat besar, dengan tujuan untuk meningkatkan daya adsorpsinya [10]. Pada proses tersebut terjadi penghilangan hidrogen, gas-gas dan air dari permukaan karbon sehingga terjadi perubahan fisik pada permukaannya. Aktifasi ini terjadi karena terbentuknya gugus aktif akibat adanya interaksi radikal bebas pada permukaan karbon dengan atom-atom seperti oksigen dan nitrogen. Karbon aktif merupakan material yang unik, karena material ini memiliki pori/celah/rongga dengan ukuran skala molekul (nanometer). Pori tersebut memiliki gaya Van Der Waals yang kuat. Sedangkan luas permukaan internal karbon aktif yang telah diteliti umumnya lebih besar dari 400 $\mathrm{m}^{2} / \mathrm{gr}$ dan bahkan bisa mencapai di atas 1000 $\mathrm{m}^{2} / \mathrm{gr}[11]$.

\section{METODE}

Alat yang digunakan untuk memurnikan biogas adalah kolom adsorpsi yang terbuat dari bahan PVC berdiameter 3" sepanjang $55 \mathrm{~cm}$, dengan $15 \mathrm{~cm}$ dijadikan sebagai dudukan kolom dan $40 \mathrm{~cm}$ sebagai kolom utama adsorpsi yang diisi dengan karbon aktif sebagai adsorben.

Biogas yang digunakan dalam penelitian ini diperoleh dari biogas milik salah seorang warga desa Cisarua, Kabupaten Bandung Barat yang memiliki kapasitas digester $4 \mathrm{~m}^{3}$ dengan tekanan biogas $4,44 \mathrm{kPa}$. Biogas tersebut dialirkan melalui selang berdiameter $1 / 2$ " ke kompor dan digunakan untuk kebutuhan memasak sehari-hari.

Dalam pengujiannya, aliran biogas sebelum memasuki kompor akan ditampung terlebih dahulu dalam plastik HDPE, kemudian biogas tersebut dilewatkan kedalam rotameter dengan tujuan untuk mengatur laju alir biogas konstan sebesar $3 \mathrm{~L} /$ menit, karena pada laju alir ini pada penelitian Purnamasari (2015) mendapatkan hasil pemurnian optimum dengan pemurnian biogas dengan 1 kolom adsorpsi [12]. Setelah laju alir biogas diatur $3 \mathrm{~L} /$ menit, kemudian biogas dialirkan melalui selang silikon ke dalam kolom adsorpsi yang didalamnya berisi karbon aktif yang nantinya telah divariasikan ukurannya.

Gas yang telah melalui kolom adsorpsi selanjutnya akan diambil sample untuk mengetahaui apakah terjadi penurunan $\mathrm{CO}_{2}$ dan kenaikan $\mathrm{CH}_{4}$ sebelum dan setelah biogas melalui kolom adsorpsi.

Untuk hasil gas yang telah melalui pemurnian selanjutnya dapat digunakan untuk keperluan memasak, menjadi bahan bakar untuk motor diesel yang telah dimodifikasi sebagai pembangkit listrik, maupun ditampung dalam tabung sebagai bahan bakar biomethana seperti CNG.

Perhitungan efektivitas penyerapan $\mathrm{CO} 2$ pada kolom adsorpsi didasarkan pada perbandingan kandungan gas $\mathrm{CO}_{2}$ dalam biogas sebelum dan setelah pemurnian atau dengan kata lain sebelum dan setelah melalui kolom adsorpsi [13].

Variabel-variabel yang diujikan adalah ukuran karbon aktif sebagai adsorben. Karbon aktif yang digunakan dibagi menjadi 3 ukuran, yakni ukuran 8 mesh, 16 mesh dan 32 mesh dengan menggunakan kolom adsorpsi yang sama, laju alir yang sama $3 \mathrm{~L} /$ menit dan lama waktu pemurnian adalah selama 15 menit. Gas yang telah melalui kolom diambil sample setiap 3 menit selama 15 menit untuk setiap ukuran karbon aktif yang digunakan dalam pemurnian biogas, dan setiap sampel gas tersebut kemudian diuji di Laboratorium Metodika Pengembangan Perancangan Proses, Labtek X Departemen Teknik Kimia ITB menggunakan Gas Chromatograph.

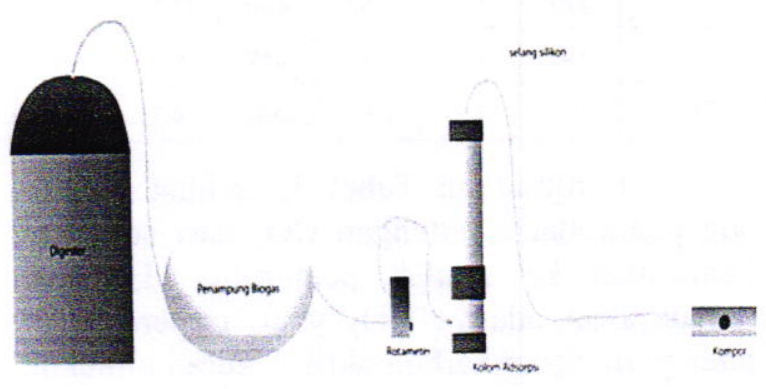

Gambar 1. Skematik Pengujian Alat 


\section{HASIL DAN PEMBAHASAN}

Sumber biogas yang digunakan pada penelitian ini adalah biogas milik warga Cisarua, Kabupaten Bandung Barat, adapun komposisi biogas sebelum pemurnian adalah seperti pada Tabel 2 berikut,

Tabel 2 Komposisi Gas Sebelum Pemurnian

\begin{tabular}{|c|c|c|}
\hline No & Komponen Gas & Komposisi (\%) \\
\hline 1 & Metana $\left(\mathrm{CH}_{4}\right)$ & 64.622 \\
\hline 2 & Karbon Dioksida $\left(\mathrm{CO}_{2}\right)$ & 28.355 \\
\hline 3 & Nitrogen $\left(\mathrm{N}_{2}\right)$ & 4.022 \\
\hline 4 & Oksigen $\left(\mathrm{O}_{2}\right)$ & 3.001 \\
\hline
\end{tabular}

Dari Tabel 2 diatas terlihat bahwa biogas yang berasal dari Desa Tugu Mukti ini masih mengandung $\mathrm{CO}_{2}$ yang cukup tinggi, yaitu sebesar $28.34 \%$ serta berbau tidak sedap akibat masih terdapatnya kandungan $\mathrm{H}_{2} \mathrm{~S}$. Nilai kandungan $\mathrm{CH}_{4}$ dan $\mathrm{CO}_{2}$ dari biogas yang digunakan sebagai gas yang akan dimurnikan sesuai dengan hasil penelitian Meynel (1997).

\section{Kandungan Gas Sebelum dan Setelah Pemurnian dengan Variasi Ukuran Karbon Aktif}

Berikut merupakan tabel perbandingan kandungan gas sebelum dan setelah pemurnian untuk berbagai macam variasi ukuran karbon aktif yang digunakan.

Tabel 3 Kandungan Gas Sebelum dan Setelah Pemurnian dengan Variasi Ukuran Karbon Aktif

\begin{tabular}{|c|c|c|c|c|c|c|}
\hline \multirow{2}{*}{$\begin{array}{c}\text { Kandungan } \\
\text { Gas }\end{array}$} & \multicolumn{5}{|c|}{ Prosentase (\%) } \\
\cline { 2 - 7 } & \multicolumn{2}{|c|}{ Ukuran 8 Mesh } & \multicolumn{2}{c|}{ Ukuran 16 Mesh } & Ukuran 32 Mesh \\
\cline { 2 - 7 } & Sebelum & Setelah & Sebelum & Setelah & Sebelum & Setelah \\
\hline $\mathrm{CO}_{2}$ & 28,32 & 7,03 & 33,56 & 7,14 & 22,24 & 2,14 \\
\hline $\mathrm{N}_{2}$ & 3,01 & 7,88 & 2,02 & 4,96 & 15,58 & 6,11 \\
\hline $\mathrm{O}_{2}$ & 2,41 & 3,77 & 1,12 & 1,69 & 5,86 & 3,92 \\
\hline $\mathrm{CH}_{4}$ & 66,26 & 81,99 & 63,3 & 86,45 & 56,32 & 88,28 \\
\hline
\end{tabular}

Berdasarkan Tabel 3, terlihat bahwa ada penurunan kandungan $\mathrm{CO}_{2}$ dari sebelum pemurnian ke setelah pemurnian. Hal ini menunjukan adanya $\mathrm{CO}_{2}$ yang terperangkap pada permukaan karbon aktif. Ukuran molekul gas akan mempengaruhi adsorpsi pada karbon aktif. Gas $\mathrm{CO}_{2}$ memiliki ukuran $0,33 \mathrm{~nm}$ dan $\mathrm{CH}_{4}$ memiliki ukuran $0,38 \mathrm{~nm}$ (Breck, dalam Lee, 2003). Dengan ukuran gas $\mathrm{CO}_{2}$ yang lebih kecil dan pori karbon aktif yang memiliki gaya van der Waalstersebut memudahkan $\mathrm{CO}_{2}$ terserap pada permukaan karbon aktif yang memiliki diameter pori ratarata $1,5 \mathrm{~nm}$ (ots.ac.id) dibandingkan $\mathrm{CH}_{4}$. Dan dengan berat molekul $\mathrm{CH}_{4}$ sebesar $16 \mathrm{~g} / \mathrm{mol}$ yang lebih ringan dibandingkan berat molekul $\mathrm{CO}_{2}(44 \mathrm{~g} / \mathrm{mol}), \mathrm{CH}_{4}$ lebih mudah berdifusi melewati permukaan karbon aktif dibandingkan $\mathrm{CO}_{2}$ yang lebih berat. Sehingga karena alasan-alasan tersebut gas $\mathrm{CO}_{2}$ yang banyak terserap pada permukaan karbon aktif dan membuat kandungan gas $\mathrm{CO}_{2}$ setelah pemurnian lebih kecil dibandingkan sebelum pemurnian yang akhirnya karena penurunan kandungan $\mathrm{CO}_{2}$ tersebut meningkatkan prosentase kandungan $\mathrm{CH}_{4}$ dan kemurnian biogas . Sedangkan untuk perbandingan hasil pemurnian dengan variasi ukuran karbon aktif terlihat seperti Gambar 2,

\section{Perbandingan Kandungan $\mathrm{CH} 4$ Setelah Pemurnian dengan Menggunakan Variasi Ukuran Karbon Aktif}

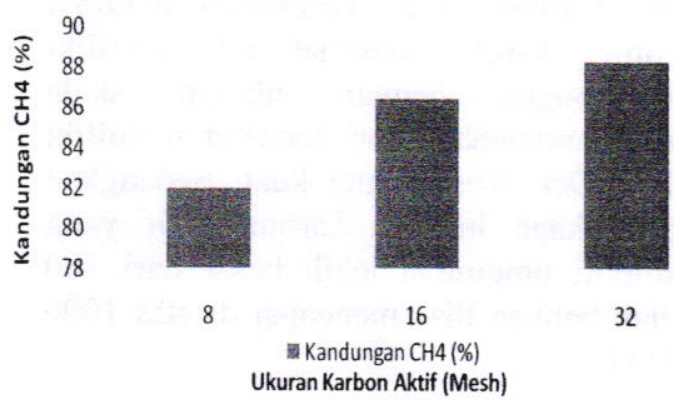

Gambar 2 Perbandingan Kandungan $\mathrm{CH}_{4}$ Setelah Pemurnian dengan Menggunakan Variasi Ukuran Karbon Aktif

Berdasarkan grafik perbandingan kandungan $\mathrm{CH}_{4}$ hasil pemurnian kandungan biogas dengan variasi ukuran karbon aktif, terlihat bahwa pada menit yang sama kandungan metana hasil pemurnian untuk setiap ukuran berbeda, terlihat bahwa kandungan metana hasil pemurnian dengan karbon aktif ukuran 32 mesh menghasilkan kandungan metan terbesar. Hal ini karena pada ukuran karbon aktif 32 mesh, luas permukaannya lebih besar sehingga penyerapan kandungan $\mathrm{CO}_{2}$ menjadi lebih besar dan efektivitas adsorpsi pun lebih tinggi, akibatnya kandungan $\mathrm{CH}_{4}$ dan nilai kalor hasil pemurnian dengan karbon aktif ukuran 32 mesh akan lebih tinggi dibandingkan dengan ukuran 8 mesh dan 16 mesh dengan menggunakan kolom adsorpsi yang sama, laju 
alir biogas yang sama dan waktu pengambilan data yang sama.

Besarnya efektivitas adsorpsi $\mathrm{CO} 2$ oleh karbon aktif salah satunya dipengaruhi oleh luas permukaan karbon aktif, dan hal yang mempengaruhi luas permukaan karbon aktif diantaranya adalah proses aktivasi dan ukuran karbon aktif. Berikut merupakan tabel perbandingan efektivitas adsorpsi untuk berbagai macam variasi ukuran karbon aktif yang digunakan.

Tabel 4 Perbandingan Efektivitas Adsorpsi Maksimum untuk Berbagai Variasi Ukuran Karbon Aktif

\begin{tabular}{|c|c|}
\hline $\begin{array}{c}\text { Ukuran } \\
\text { Karbon Aktif }\end{array}$ & $\begin{array}{c}\text { Efektivitas Adsorpsi } \\
(\%)\end{array}$ \\
\hline 8 & 75,17 \\
\hline 16 & 78,73 \\
\hline 32 & 90,37 \\
\hline
\end{tabular}

Berikut merupakan tabel perbandingan nilai kalor biogas setelah proses pemurnian untuk berbagai macam variasi ukuran karbon aktif yang digunakan

Tabel 5 Perbandingan Nilai Kalor Sebelum dan Setelah Pemurnian Dengan Variasi Ukuran Karbon Aktif

\begin{tabular}{|c|c|c|}
\hline \multirow{2}{*}{$\begin{array}{c}\text { Ukuran } \\
\text { Karbon Aktif }\end{array}$} & \multicolumn{2}{|c|}{ Nilai Kalor $\left(\mathbf{k J} / \mathbf{m}^{3}\right)$} \\
\cline { 2 - 3 } & $\begin{array}{c}\text { Sebelum } \\
\text { Pemurnian }\end{array}$ & $\begin{array}{c}\text { Setelah } \\
\text { Pemurnian }\end{array}$ \\
\hline $\begin{array}{c}\text { Ukuran 8 } \\
\text { Mesh }\end{array}$ & 19868,96 & 26904,84 \\
\hline $\begin{array}{c}\text { Ukuran 16 } \\
\text { Mesh }\end{array}$ & 20523,98 & 28365,61 \\
\hline $\begin{array}{c}\text { Ukuran 32 } \\
\text { Mesh }\end{array}$ & 18480,22 & 28968,86 \\
\hline
\end{tabular}

Besarnya efektivitas adsorpsi akan berbanding lurus dengan selisih kandungan $\mathrm{CO}_{2}$ sebelum dan setelah pemurnian. Dengan kata lain semakin kecil kandungan $\mathrm{CO}_{2}$ setelah pemurnian dan semakin besar selisih kandungan $\mathrm{CO}_{2}$ sebeum dan setelah pemurnian, maka menunjukkan efektivitas kolom adsorpsi akan semakin besar. Dari grafik perbandingan kandungan $\mathrm{CO}_{2}$ sebelum dan setelah pemurnian dengan variasi ukuran karbon aktif, nilai efektivitas adsorpsi dengan ukuran karbon aktif 8 mesh maksimum hanya $75,17 \%$ dan nilai efektivitas adsorpsi dengan ukuran karbon aktif 16 mesh maksimum hanya $78,73 \%$. Sementara dengan menggunakan karbon aktif ukuran 32 mesh efektivitas adsorpsi dapat mencapai $90,37 \%$ pada menit ke-9 selama adsorpsi. Hal ini karena pada ukuran karbon aktif 32 mesh, luas permukaannya lebih besar sehingga penyerapan kandungan $\mathrm{CO}_{2}$ menjadi lebih besar karena jumlah molekul adsorbat yang teradsorpsi meningkat dengan bertambahnya luas permukaan dan volume pori adsorben [8], sehingga efektivitas adsorpsi pun lebih tinggi dibandingkan dengan ukuran 8 mesh dan 16 mesh walaupun dengan menggunakan kolom adsorpsi yang sama, laju alir biogas yang sama dan waktu pengambilan data yang sama.

Setiap nilai kalor yang dihasilkan oleh proses pemurnian biogas menggunakan karbon dengan ukuran 8 mesh, 16 mesh dan 32 mesh akan berbeda, karena kandungan metana $\left(\mathrm{CH}_{4}\right)$ hasil pemurnian dengan setiap ukuran karbon aktif tersebut juga berbeda, sedangkan nilai kalor biogas akan sangat tergantung pada kandungan metana $\left(\mathrm{CH}_{4}\right)$ dalam biogas.

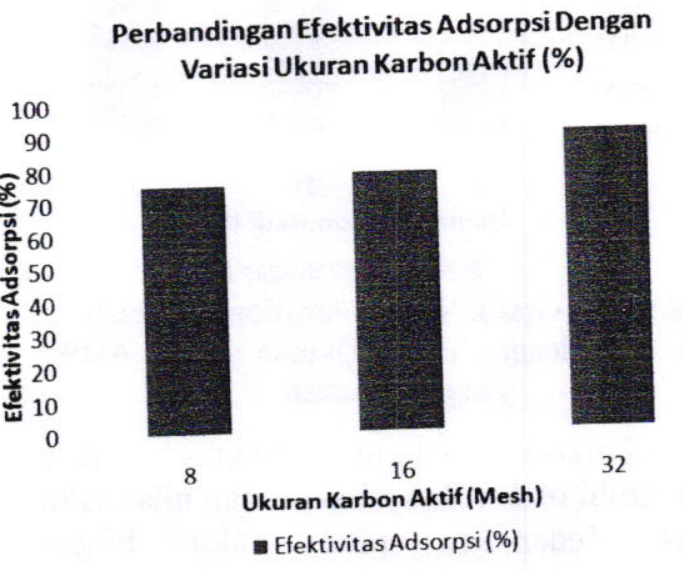

Gambar 3 Grafik PerbandinganEfektivitas adsorpsi $\mathrm{CO}_{2}$ dengan Variasi Ukuran Karbon Aktif

Nilai kalor biogas akan berbanding lurus dengan kandungan metana pada biogas, sehingga sesuai dengan grafik perbandingan nilai kalor hasil pemurnian biogas dengan variasi ukuran karbon aktif, terlihat bahwa nilai kalor biogas hasil pemurnian dengan ukuran karbon aktif 32 mesh lebih tinggi dibandingkan dengan hasil pemurnian dengan karbon aktif ukuran 8 mesh dan 16 mesh.

Pada hasil pemurnian dengan ukuran karbon aktif 32 mesh nilai kalor biogas mencapai $28968.86 \mathrm{~kJ} / \mathrm{m}^{3}$ sedangkan nilai kalor biogas setelah pemurnian dengan karbon aktif ukuran 8 mesh hanya $23317,38 \mathrm{~kJ} / \mathrm{m}^{3}$ dan dengan karbon aktif ukuran 16 mesh mencapai $28365,61 \mathrm{~kJ} / \mathrm{m}^{3}$. Hal ini karena pada ukuran karbon aktif 32 mesh, luas permukaannya 
lebih besar dan area kontak karbon aktif dengan $\mathrm{CO}_{2}$ pun lebih banyak, sehingga penyerapan kandungan $\mathrm{CO}_{2}$ menjadi lebih besar dan efektivitas adsorpsi pun lebih tinggi, akibatnya kandungan $\mathrm{CH}_{4}$ meningkat sehingga nilai kalor hasil pemurnian dengan karbon aktif ukuran 32 mesh akan lebih tinggi dibandingkan dengan ukuran 8 mesh dan 16 mesh dengan menggunakan kolom adsorpsi yang sama, laju alir biogas yang sama dan waktu pengambilan data yang sama dan akhirnya nilai kalor biogas hasil pemurnian dengan ukuran karbon aktif 32 mesh lebih tinggi dibandingkan nilai kalor biogas hasil pemurnian dengan ukuran mesh dan 16 mesh.

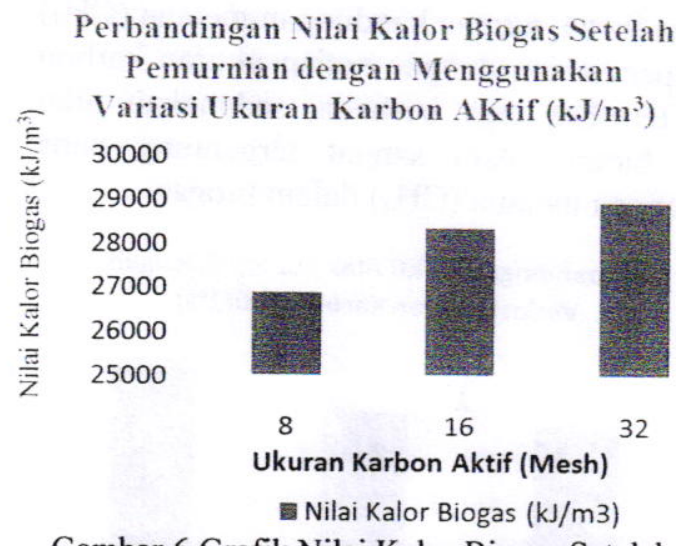

Gambar 6 Grafik Nilai Kalor Biogas Setelah Pemurnian dengan Variasi Ukuran Karbon Aktif yang Digunakan

Potensi energi biogas akan dipengaruhi oleh volume biogas dan nilai kalor biogas, sedangkan nilai kalor biogas bergantung kepada kandungan $\mathrm{CH}_{4}$ dalam biogas, sehingga semakin tinggi kandungan metana dalam biogas akan membuat nilai kalor biogas semakin tinggi pula dan akhirnya meningkatkan potensi energi biogas. Dari hasil pengukuran yang dilakukan, variasi ukuran karbon aktif mempengaruhi efektivitas adsorpsi dan kandungan metana setelah pemurnian sehingga membuat potensi energi biogas yang dihasilkan setelah pemurnian oleh setiap ukuran akrbon aktif juga berbeda, adapun perbandingan potensi energi biogas setelah pemurnian dengan variasi ukuran karbon aktif selama 15 menit diperlihatkan pada gambar 7 . Terlihat bahwa potensi energi biogas setelah pemurnian dengan karbon aktif ukuran 32 mesh menghasilkan potensi energi biogas tertinggi yakni $476,524 \mathrm{~kJ}$ selama 15 menit (setara $0,530 \mathrm{~kW}=530$ Watt), sedangkan untuk potensi energi biogas setelah pemurnian dengan karbon aktif ukuran 8 mesh dan 16 mesh masing-masing adalah 426,750 $\mathrm{kJ}$ (setara 0,474 kW) dan 431,381 kJ (setara $0,479 \mathrm{~kW})$.

Perbandingan Potensi Energi Biogas Setelah Pemurnian dengan Variasi Ukuran Karbon Aktif (kJ)

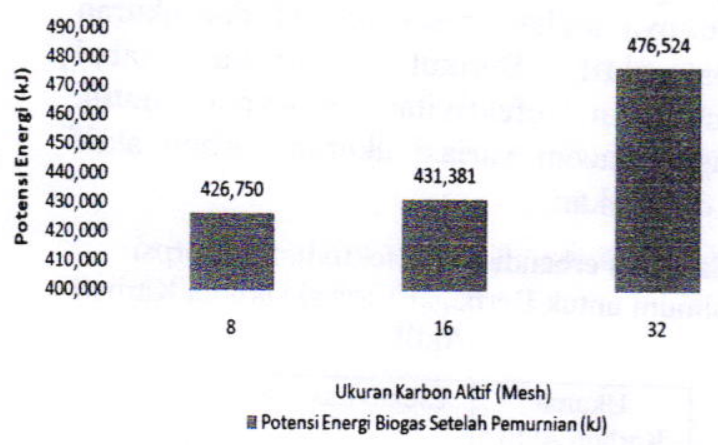

Gambar 7 Grafik Potensi Energi Biogas Setelah Pemurnian dengan Variasi Ukuran Karbon Aktif yang Digunakan

Hal tersebut memperlihatkan bahwa semakin kecil ukuran karbon aktif yang digunakan sebagai adsorben menghasilkan potensi energi biogas setelah pemurnian yang semakin tinggi, hal ini karena semakin kecil ukuran karbon aktif, semakin besar luas permukaan karbon aktif dan dengan semakin besar luas permukaan karbon aktif akan membuat jumlah adsorbat yang diserap adsorben menjadi semakin banyak dan meningkatkan efektivitas adsorpsi (Suryawan, 2004). Sehingga membuat kandungan $\mathrm{CH}_{4}$ setelah pemurnian semakin tinggi yang membuat nilai kalor biogas semakin tinggi dan akhirnya membuat potensi energi biogas semakin tinggi pula, karena potensi energi biogas sangat dipengaruhi oleh tingginya kandungan $\mathrm{CH}_{4}$ dalam biogas.

\section{KESIMPULAN}

1. Pada penelitian ini dengan volume kolom yang sama semakin kecil ukuran karbon aktif, semakin tinggi efektivitas adsorpsi, kandungan $\mathrm{CH}_{4}$ setelah pemurnian dan potensi energi biogas setelah pemurnian

2. Hasil pemurnian biogas terbaik yakni dengan menggunakan karbon aktif ukuran 32 mesh dengan menghasilkan efektivitas adsorpsi $90,37 \%$, kandungan $\mathrm{CH}_{4}$ setelah pemurnian mencapai $88,28 \%$, nilai kalor biogas setelah pemurnian $=28968,86$ $\mathrm{kJ} / \mathrm{m}^{3}$ dan potensi energi biogas setelah pemurnian selama 15 menit, 
3. Hasil pemurnian biogas dengan kolom adsorpsi bervolume 2,43 liter dengan karbon aktif ukuran 8 dan 16 mesh menunjukan karbon aktif mulai jenuh pada menit ke-15, sedangkan karbon aktif ukuran 32 mesh mulai jenuh pada menit ke-30.

\section{DAFTAR PUSTAKA}

[1] Meynell.(1976). Metahne: Planning a Digester. GreatBritain : Prism Press.

[2] Susanto, Heru., dkk. Modifikasi Karbon Aktif Sebagai Adsorben Untuk PemurnianBiogas. Universitas Dipenegoro

[3] Bamboriya, M.L.. (2013). Biogas Generation, Purification And Bottling: Development In India. India

[4] LIPI, 2016, "LIPI Temukan Cara Tingkatkan Kualitas Biogas", http://lipi.go.id/berita/single/LIPITemukan-Cara-Tingkatkan-KualitasBiogas/12293

[5] T.A. Seadi, D. Rutz, H. Prassl, "Biogas handbook", University of Southern Denmark Esbjerg, Denmark 2008

[6] Fitria, B., 2009, "Biogas", http://biobakteri.wordpress.com/2009/06/ 07/8-biogas
[7] Benefield.(1982). Process Chemistry for Water and Waste Water Treatment. Prentice Hall Inc. New Jersey.

[8] Suryawan, Bambang. (2004). "Karakteristik Zeolit Indonesia sebagai Adsorben Uap Air". Universitas Indonesia.

[9] Oscik, J.(1982). "Adsorption", Ellis Horwood Limited, Publisher.

[10] Arfan Y.(2006)."Pembuatan Karbon Aktif Berbahan Dasar Batubara Dengan Perlakuan Aktivasi Terkontrol Serta Uji Kinerjanya". Depok : Departemen Teknik Kimia FT-UI.

[11] Sudibandriyo, M., "A Generalized OnoKondolatice Model for High Pressure on Carbon Adsorben", Ph. Dissertation: Oklahoma: Oklahoma State University, 2003.

[12] Purnamasari, Wulan. (2015). Pembuatan Dan Pengujian Alat Pemurnian Biogas Susunan Seri Dengan Metode Adsorpsi Menggunakan Adsorben Karbon Aktif . Bandung : Politeknik Negeri Bandung.

[13] Widyastuti, Apria. dkk.(2013) . Karbon Aktif Dari Limbah Cangkang Sawit Sebagai Adsorben Gas Dan Biogas Hasil Hasil Fermentasi Anaerobik Sampah Organik. Hal 30-33. 